\title{
Automating Bibliographic Research: Identifying American Fiction, 1901-1925
}

\section{Geoffrey D. Smith, Diane Vizine-Goetz and Edward T. O'Neill}

\begin{abstract}
The American Fiction Project of the Ohio State University Libraries was the focus of a cooperative research effort between Ohio State and the OCLC Office of Research. The purpose of the American Fiction Project was to improve access to Ohio State's early twentieth-century American fiction collection and to identify and acquire new titles for the collection. For its part, OCLC identified catalog records in the OCLC database-the Online Union Catalog-for items suspected to be within the project's scope (American fiction published from 1901 through 1925). The results and analysis of the sample records suggest that the methodology employed can be of great assistance for the compilation of comprehensive bibliographies and for collection development.
\end{abstract}

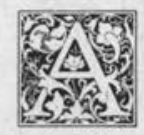

merican fiction has long been a focus of collection development at the Ohio State University Libraries. Ohio State's William Charvat Collection of American Fiction (fiction from 1787 through 1900) compares favorably with similar collections at the American Antiquarian Society, Yale University, the Library of Congress, Harvard University, and the Huntington Library. Ohio State's holdings are particularly strong in the 1876-1900 period. Additionally, Ohio State possesses a generous number of American fiction titles (including many first editions) from 1901 through 1925 in its general collection. In the late 1950 s, this collection was further strengthened by the purchase of a large collection of American literature from the Library Company of Philadelphia. Many titles of American fiction, especially publications from the first quarter of the twentieth century, were included in this acquisition.
Recognizing the significance of its early twentieth-century American fiction collection, Ohio State began a project to establish a comprehensive bibliographic file of fiction for the period and to improve bibliographic access to the collection. The project is referred to as the American Fiction Project (AFP). ${ }^{1}$ Its specific purpose is to identify, acquire, and catalog, in full accord with national standards, the corpus of American fiction published from 1901 through $1925 .^{2}$ At present, Ohio State's holdings in this subject area-more than 10,000 titles - are rivaled only by the holdings of the Library of Congress. Providing ready access to the materials will be of significant value to scholars of literary history, publishing and printing history, and book illustration and design. Moreover, since popular fiction expresses social, political, economic, and religious attitudes of the times, the American fiction collection will also be useful for research in other hu-

Geoffrey D. Smith is Curator of The William Charvat Collection of American Fiction at Ohio State University Libraries, Columbus, Ohio 43210. Diane Vizine-Goetz is Research Scientist and Edward T. O'Neill is Senior Research Scientist at OCLC Online Computer Library Center, Dublin, Ohio 43017-0702. 
manistic disciplines, such as history, sociology, anthropology, and folklore.

The Office of Research of the OCLC Online Computer Library Center, in a collaborative research effort with the Division of Special Collections at Ohio State, identified catalog records in the OCLC database-the Online Union Catalog-for items suspected to be within the project's scope. As a result of these efforts, many titles of American fiction that have been overlooked in previous scholarly research will become part of the canon of American literary and cultural history.

The cooperative effort of OCLC and Ohio State proved beneficial to both parties: OCLC was able to compare its bibliographic database against an established bibliographic file; Ohio State was able to use the OCLC database to refine and further enrich its bibliographic file of American fiction for the period.

\section{THE AMERICAN FICTION PROJECT BIBLIOGRAPHY}

As a consequence of the effort to organize its current holdings and acquire new titles from the period, a comprehensive bibliography of American fiction is being created by Ohio State. The criteria for selection of titles in the bibliography are modeled after Lyle $\mathrm{H}$. Wright's bibliographic work in earlier American fiction, i.e., first American book appearance of adult fiction by American authors during the period. Included are "novels, short stories, tall tales, allegories, tract-like tales, and fictitious biographies and travels. "'3

AFP's extensive working bibliography was compiled from a number of sources, including R. Glenn Wright's Chronological Bibliography of English Fiction in the Library of Congress through 1950 and the PZ 1 shelflist (short fiction) of the Library of Congress. ${ }^{4}$ This file was enriched through comparison with the Huntington Library's file of American fiction, 1901-1930 (on loan to Ohio State through the courtesy of the Huntington Library), the New York Public Library's Dictionary Catalog of the Research Libraries, copyright records, and listings in Publishers Weekly.

More than 350 additional bibliographic sources have been examined for confirmation of existing AFP records and discovery of new records. These sources include standard guides to American studies such as Bibliographical Guide to the Study of the Literature of the U.S.A. ${ }^{5}$ and Tanselle's Guide to the Study of United States Imprints; ${ }^{6}$ regional bibliographies such as An Annotated Bibliography of California Fiction, $1664-1970^{7}$ and Ohio Authors and Their Books; ${ }^{8}$ genre bibliographies such as The Checklist of Science-Fiction and Supernatural Fiction' and The Novels of World War I: An Annotated Bibliography; ${ }^{10}$ and author bibliographies including A Golden Anniversary Bibliography of Edgar Rice Burroughs ${ }^{11}$ and $A$ Bibliography of Christopher Morley. ${ }^{12} \mathrm{Nu}-$ merous cultural and historical studies, critical studies, biographies, and book dealer catalogs were also consulted.

The working American fiction bibliographic file is a manual file that comprises thirty boxes of index cards. The file contains catalog records of appropriate items and records of authors and titles deemed inappropriate for inclusion in the bibliography. (Inappropriate records are designated "omits.") Thus, the working bibliographic file contains more records than the approximately 13,000 titles confirmed to be first American printings by American fictionists from 1901 through 1925. The majority of "omitted" records are for foreign authors, collections of anecdotes, juvenile works, jest books, folklore, essays, periodical fiction, and reprints of earlier American fiction. The omissions follow the criteria established by Lyle Wright in his work on pre-1901 American fiction. The omitted titles and authors are important to the file, for substantial research is often required to determine whether or not an author or title is appropriate for inclusion. By retaining "omits" in the working file, redundant research efforts can be prevented when the omitted authors or titles appear in other bibliographic sources.

\section{THE OCLC DATABASE AS AN AID TO LITERARY RESEARCH AND BIBLIOGRAPHY}

Catalog records in the OCLC database that met the general requirements of AFP 
were identified by OCLC. The offline search was limited to OCLC machinereadable cataloging (MARC) records in the books format entered into the database prior to July 1985 . Some records, however, containing cataloging that was judged to be incomplete or unreliable were excluded from consideration. Examples of such records are (1) minimal-level records, (2) cataloging-in-publication records, (3) order-level records, and (4) errorand-warning-level records.

A search was performed using a recordidentification algorithm based on the project's title selection criteria: the first American book appearance of adult fiction published between 1901 and 1925 . The algorithm used the data elements classification number, fiction code, publication date, and juvenile work code in a series of tests to identify candidate records with the following characteristics: (1) fiction, (2) published during the specified period, and (3) not a juvenile work. The algorithm was applied as follows:

1. Database searches were performed to find all records classed as American fiction according to the Library of Congress Classification (LCC) or the Dewey Decimal Classification (DDC). The class numbers used are given in tables 1 and 2 . When a record contained both an LCC number and a DDC number, the LCC number was preferred. Records that did not match on classification number were rejected except for unclassed records. Records that contained no classification number were retained because many libraries, especially public libraries, do not classify fiction.

2. Unclassed records and records that

TABLE 1

\section{LIBRARY OF CONGRESS CLASSES FOR AMERICAN FICTION}

\begin{tabular}{ll}
\hline $\begin{array}{l}\text { Class } \\
\text { Number/Range }\end{array}$ & \multicolumn{1}{c}{\begin{tabular}{c}
\multicolumn{1}{c}{ Class Number } \\
Description
\end{tabular}} \\
\hline PS 991-3369 & $\begin{array}{l}\text { American authors, } \\
\text { 19th century } \\
\text { American authors, } \\
\text { PS 3500-3549 }\end{array}$ \\
PZ 1 & $\begin{array}{l}\text { Fiction in English, } \\
\text { Collections }\end{array}$ \\
PZ 3 & $\begin{array}{l}\text { Fiction in English, } \\
\text { Individual authors 1750-1950 }\end{array}$ \\
&
\end{tabular}

TABLE 2

DEWEY DECIMAL CLASSES FOR AMERICAN FICTION

\begin{tabular}{ll}
\hline $\begin{array}{l}\text { Class } \\
\text { Number/Range }\end{array}$ & \multicolumn{1}{c}{$\begin{array}{c}\text { Class Number } \\
\text { Description }\end{array}$} \\
\hline 813 & Fiction \\
817 & Satire and humor \\
818 & Miscellaneous writings \\
\hline
\end{tabular}

matched on classification number were then checked to determine if the item was published between 1901 and 1925, inclusive. Records that passed the publication date test were then checked to determine if the record was for a juvenile work. Records for juvenile works were rejected. Records with the specified classification numbers were saved for listing. The remainder of the algorithm was applied to the unclassed records.

3 . The fiction code was checked to determine if the record was for a work of fiction. Records identified as fiction were saved for listing.

4. An unclassed record not identified as fiction was listed only when it met all of the remaining tests:

a. language is English;

b. published in the United States;

c. not a government document;

d. not a conference publication.

Records for reprints were included in the listings even though AFP's bibliographic file is limited to first editions. There are several reasons for this decision. A copy of the original edition may not be held by an OCLC member institution. It is even possible that no copy of the original edition exists, and the reprint may be the closest derivative of the original edition. More likely, however, the work is held by a member institution but was cataloged long before OCLC was formed. Therefore, no bibliographic record for the item would be found in the OCLC database unless the record had been entered retrospectively. In any case, the information obtained from the reprint is often sufficient to identify the original edition using other bibliographic tools.

Even when the original edition is available, information about reprints establishes a book's popularity and forms the basis for determining the complete biblio- 
graphic transmission of a text, an important aspect of a complete, ideal bibliography. Nevertheless, a reprint edition does not always indicate wide sales or circulation of the original edition. For instance, limited editions of organizational or church materials might warrant reprinting, or privately published novels may eventually be released by a sympathetic publisher as reprints (though actually the first trade edition).

Records identified by the database search were printed alphabetically by author and title, with some variation due to machine alphabetization capabilities. For example, diacritical marks divided an author's surname, resulting in alphabetical arrangement by the syllables preceding the diacritical mark (e.g., Benét becomes Ben et, arranged alphabetically following Below and preceding Benchley). Also, the grammatical articles ( $a, a n$, and the) were included as first words in titles. Records were confined to one line with the following information in sequence: OCLC number, date of publication, author's surname, and title (see figure 1). Computer listings were further divided by classification: LCC PS and PZ: DDC 813 and 817-818; unclassified with fiction indicator; and unclassified without fiction indicator.

The output format was suitable for comparison to AFP's bibliographic file, which is also arranged alphabetically by author and title. Since the printed output, even in abbreviated form, numbered more than 900 pages, listings of full OCLC record printouts were impractical in terms of convenience, cost, and time. For rapid comparison of OCLC records with AFP records, the abbreviated records provided sufficient data in the vast majority of cases (although, in retrospect, full authors' names would have been desirable) and allowed for easy record keeping. Finally, the full OCLC record could be retrieved by OCLC number when additional information was needed.

\section{EVALUATION OF THE OCLC SEARCH RESULTS}

The results of the search of the OCLC database for potential catalog records of
American fiction published between 1901 and 1925 were analyzed by the Ohio State University Libraries. To ensure a thorough analysis, a sampling of approximately $10 \%$ of the AFP's card file (three of thirty boxes, arranged alphabetically by author and extending from $A$ through $B r o u)$ was compared with the equivalent sampling of the OCLC records ( $A$ through Brou, 4,798 author and title entries of 49,408 total entries). The remaining $90 \%$ of the records will be checked in a more cursory manner, i.e., looking for new titles only. What might appear as an onerous analysis (4,798 title entries) was mitigated by experience. The AFP bibliographer, familiar with the fiction of the period and American literature generally, was able to eliminate many titles on sight inspection of the OCLC listings. Reprints of works by popular authors such as Louisa May Alcott or John Kendrick Bangs were recognized as inappropriate to project scope. In many cases, nonfiction titles (poetry, drama, essays, biographies) were either known to be nonfiction or described as such in the title or subtitle (e.g., Selected Poems of Craven Langstroth Betts or Jacob Leisler: A Play of Old New York). Juvenile works, such as L. Frank Baum's Rinkitink in $\mathrm{Oz}$, were also easily identified. Since fiction can be assigned any title by its author, however, no record was omitted on sight inspection unless the bibliographer was certain of its inappropriateness for the AFP file.

The $10 \%$ AFP sample file yielded 1,247 titles appropriate for inclusion in a bibliography of American fiction within the established criteria. The corresponding OCLC sample contained 910 of the 1,247 titles, a $72.9 \%$ hit rate. Since the AFP file has been developed over a five-year period, a $72.9 \%$ hit rate of appropriate titles is significant. Further analysis of the sample file indicated that 1,033 titles were derived from R. Glenn Wright's Chronological Bibliography of English Fiction in the Library of Congress through 1950 and 214 additional titles from research of other printed sources by AFP staff.

A comparison of the OCLC catalog records with the bibliographic records derived from R. Glenn Wright's bibliogra- 


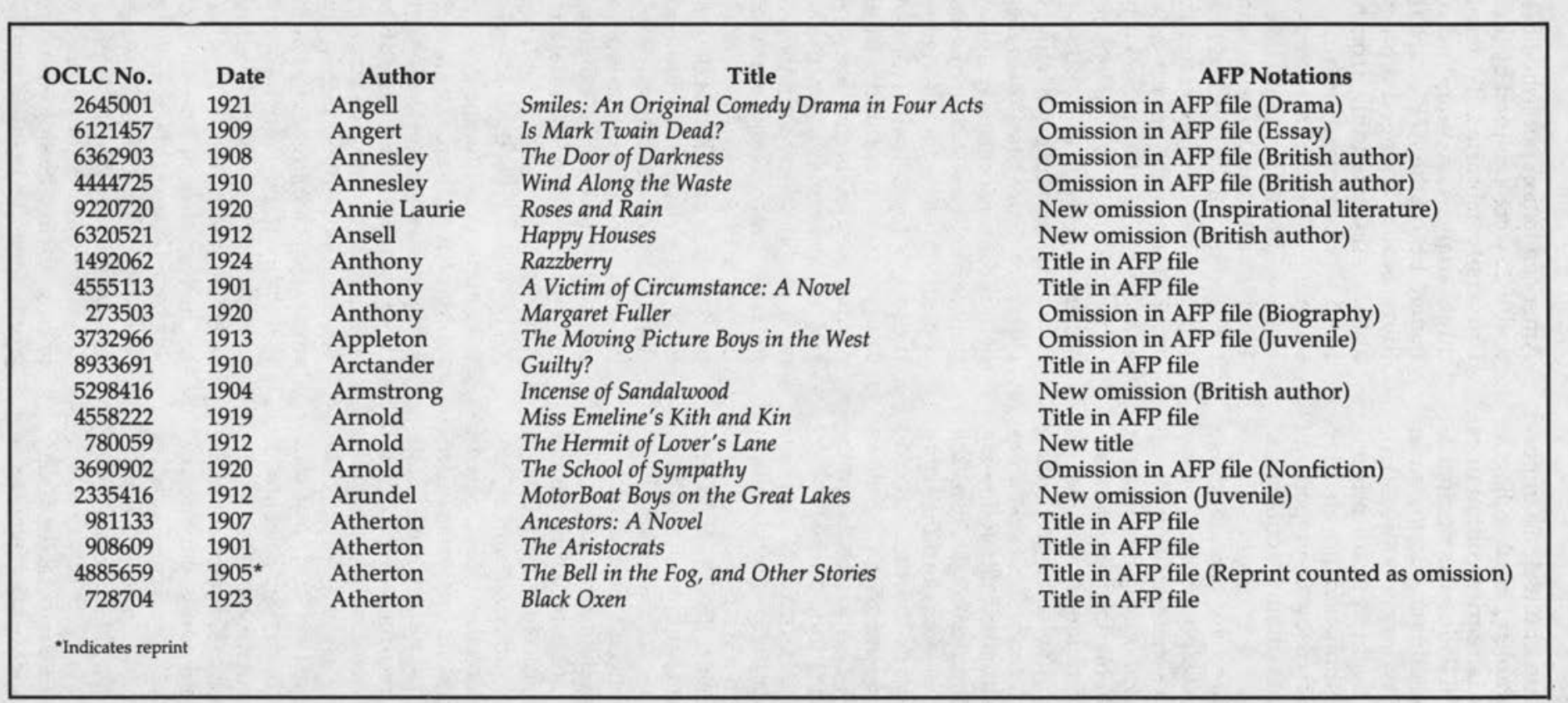

FIGURE 1

Sample printout of records identified by OCLC database search 
phy, however, indicates further the efficacy of bibliographic utility database searching as an initial step in the creation of broad-ranging bibliographic files, such as a period or genre bibliography. As mentioned above, the majority (approximately $83 \%$ ) of records in the AFP file was derived from Wright's bibliography. The Wright bibliography is a reproduction of the Library of Congress' shelflist, completed in 1973, for fiction of the English-speaking world.

Researchers examined each record in Wright to determine its potential for inclusion in a bibliography of American fiction published between 1901 and 1925; made copies of possible inclusions, which were mounted on index cards and filed by author name; researched pertinent bibliographic sources to ascertain eligibility for the file; checked Ohio State's online catalog for institutional holdings; and, finally, coded the cards with additional, relevant information discovered during the research process. The OCLC search results contained 970 of the 1,033 Wright titles in the $10 \%$ sample, or $93.9 \%$ of the original American fiction card file. Compilers of a comparable bibliographic file (e.g., American fiction, 1926-1950), then, could expect, prior to consulting printed sources, a base file of OCLC records to include a high percentage of appropriate titles.

These statistics indicate two major points: traditional research of printed bibliographies are essential for establishing a thorough bibliography of American fiction; but, online databases, such as the OCLC database, can aid in establishing a significant bibliographic file $(72.9 \%$ of the titles discovered over a five-year period) in about one quarter the time.

\section{DISCOVERY OF NEW TITLES}

For AFP, the discovery of new titles was preeminent during the analysis of the OCLC search results. Thirty new titles were discovered-seven by examination of complete OCLC catalog records and research of in-house reference tools (e.g., National Union Catalog, Publishers Weekly) and twenty-three by inspection of texts or photocopies obtained through interlibrary loan. To date, an additional eleven titles could not be confirmed as either fiction or nonfiction after in-house research. The unconfirmed titles are being requested through interlibrary loan for inspection. The results of the analysis are shown in table 3 .

\section{TABLE 3}

\section{ANALYSIS OF OCLC SAMPLE}

\begin{tabular}{lr}
\hline Titles in AFP file & 910 \\
Omissions in AFP file & 3,152 \\
Duplicate editions & 91 \\
Authors in AFP file under variant name & 21 \\
New omissions & 583 \\
New titles & 30 \\
Unconfirmed titles & 11 \\
Total & 4,798 \\
\hline
\end{tabular}

The confirmation of thirty titles, previously unrecorded after years of intensive research, is noteworthy. Twenty-six were by authors not previously in the American fiction file. The titles were either not listed as fiction in the many traditional printed sources or, in one case, not listed in any of the sources consulted, including the $\mathrm{Na}$ tional Union Catalog. For instance, neither National Union Catalog nor National Union Catalog Supplements showed a record for Mary E. Bell's Mammy's Story and Verses. ${ }^{13}$ In short, the thirty titles might well have remained unidentified as American fiction if not for the OCLC database and this project. Projecting on the $10 \%$ sample of a total of thirty new titles, AFP can anticipate uncovering approximately 300 new titles through OCLC research efforts. Of the thirty new titles identified to date, twenty were from LCC PS, six from LCC PZ, two from unclassified records with fiction indicator, one from unclassified records without fiction indicator, and one from DDC.

Since the AFP bibliographic file was compiled principally from the LC PZ shelflist, a greater number of new titles from LCC PS, as compared to PZ, would be expected, though six titles from PZ is not insignificant. The new titles from PS can be attributed, in part, to classifying principles that require a work to be classed with the predominant subject or form. Classifying a work as poetry, essays, miscellanies, etc., often inhibits the identification of fiction included in the text. In some 
cases, fictional pieces may be distinct works with no relation to the overall structure of the text; in other cases, the fiction may be an integral and unifying element of the work's total concept. One method for identifying LCC PS for fiction, outside of OCLC's search of its database, would be to screen the LC shelflist, as R. Glenn Wright did for LCC PZ (ten years of research according to Wright). ${ }^{14}$ Two new titles from the unclassified catalog records justify searching unclassified materials. The one new title in the DDC listings is accounted for, principally, by the order of the OCLC search that used LCC classes when both LCC and DDC numbers were present, although the DDC records may yet yield more results in the complete analysis.

\section{SIGNIFICANCE OF NEW TITLES}

Equally important as the number of new titles located is the importance of the texts and themes themselves. Several of the new titles address pertinent literary, historical, and cultural themes of the period that are of special interest to scholars. Adam Abet's Social Conscience ${ }^{15}$ addresses ethnic intolerance and nationalism on the American home front during World War I. In a more positive vein, Samuel Hopkins Adams, in The Beggar's Purse, ${ }^{16}$ provides a humorous account of the need for fiscal restraint and sacrifice at home while the doughboys are fighting the war to end all wars. More than fifteen years prior to the Prohibition Act, Kate Anderson, in A Fight Against Odds, ${ }^{17}$ dramatized the prevalent view toward the destructive influences of alcohol. Occasionally, an author presents a sympathetic, though often patronizing, view of black America's strides toward equality, as Isabella Andrews does in The Failure of Cunningham. ${ }^{18}$ More often, however, writers of the period perpetuated the plantation myth and stereotypes of superstitious, indigent blacks, as does Julia Keim Baker in The Wandering Joy ${ }^{19}$ and C. $\mathrm{H}$. Beazley in Crackerlings and Caramels. ${ }^{20}$ In The Inscrutable Woman, ${ }^{21}$ Edward David Baron depicts the ethnic prejudice against numerous immigrant groups. Though most of these works are examples of neither great literary craft nor social enlight- enment, they are reflective of American sentiment of the period and may actually represent the majority view from the common man's experience.

Many of the newly identified titles emanate from special interest or regional and local presses. Other presses, in addition to those cited for the works above, include Billington Press of Ossining, New York; L. Graham Co. of New Orleans; Hunter and Co., Richmond, Virginia; Stockton Press, Baltimore, Maryland; J. P. Bell Co., Lynchburg, Virginia; and Broadman Press, Nashville, Tennessee. Identification of little-known presses may initiate investigation into regional publishing activities as distinct cultural statements about local perceptions and attitudes. In the case of both subject matter and regional expression, these new titles will be all the more valuable to scholars because of their omission from traditional printed sources. In addition, G. Thomas Tanselle has noted publishing history's "undeniable relevance . . . for meaningful literary history"; he notes further "that we do not have a complete inventory of regional imprints, nor histories of all significant publishers, small and large, nor analyses of all book-publishing centers, nor edited versions of all important records of publishing firms.",22

Archives of the major publishing houses of the period are generally available. Houghton Mifflin, for instance, maintains its own library of company archives and the National Union Catalogue of Manuscript Collections lists numerous additional materials about Houghton Mifflin, including papers of company officers and correspondence of authors. The archives of Harper and Brothers, located at Columbia University, are now available on microfilm for the years $1817-1914 .^{23}$ It is likely, however, that few if any records exist for small presses from three-quarters of a century ago. The products of those presses, the books themselves, may be the sole, primary sources of diverse regional and sectarian publishing activities. In addition, since these small presses, by financial restrictions alone (not overlooking their specialized market) seldom, if ever, advertised or announced titles in the trade 
journals (principally Publishers Weekly and the Publishers' Trade List Annual), the OCLC search results will be a substantial beginning for investigation of regional publishers of fiction. For instance, the inordinate number of local southern publishers may suggest an effort by those businessmen to promote a different view of American society than the one the mainstream, eastern publishing centers were providing. The addition of these titles to a bibliographic file of American fiction, then, should aid scholarly research into local and regional historical culture; for, addressed to limited, local audiences, and hence concerned with local issues, regional fiction is less inhibited by social and political constrictions that affect the subject matter and presentation of nationally distributed fiction of the period.

\section{THE AMERICAN FICTION PROJECT BIBLIOGRAPHIC DATABASE}

Titles appropriate to project scope are cataloged $(6,000$ titles to date) on the OCLC system and entered onto a discrete database of machine-readable bibliographic records maintained by Ohio State. Cataloging for the project goes beyond traditional cataloging information to include "rare book" transcription of the pagination; provide access points to names of publishers, printers, illustrators, and binding designers (when applicable); and denote established sources of bibliographic reference.

The American Fiction Project, an ongoing project, will add the new titles to its database, which, when completed, will be available to institutions and individuals on computer output microfiche as well as magnetic tape.

\section{SUMMARY}

From American Fiction Project's perspective, OCLC's search results proved useful for enrichment and refinement of AFP's bibliographic file. The results and analysis suggest that the methodology employed can be of great assistance to bibliographic scholars. Furthermore, OCLC and AFP's cooperative research and analysis will have very real benefits for the library and scholarly community in the form of the American fiction database. The joint endeavor will be a distinct contribution to literary research in terms not only of increasing access to materials, but also in developing innovative research methods that will influence the direction of future scholarship.

\section{REFERENCES AND NOTES}

1. The American Fiction Project's Final Technical Report to the U.S. Department of Education is available on ERIC, ED 260730.

2. From April 1983 through March 1985 the American Fiction Project operated under two one-year grants from the U.S. Department of Education's Strengthening Research Library Resources program (Title II-C of the Higher Education Act) in order to purchase and begin full cataloging of American fiction from the first quarter of the twentieth century.

3. American Fiction, 1876-1900: A Contribution toward a Bibliography (San Marino, Calif.: Huntington Library, 1966), p.ix.

4. R. Glenn Wright, Chronological Bibliography of English Fiction in the Library of Congress through 1950 (Boston: G. K. Hall, 1974).

5. Clarence Gohdes and Sanford E. Marovitz, Bibliographic Guide to the Study of the Literature of the U.S.A., 5th ed. (Durham, N.C.: Duke University Press, 1984).

6. G. Thomas Tanselle, Guide to the Study of United States Imprints, 2v. (Cambridge: Belknap Press, 1971).

7. Newton D. Baird and Robert Greenwood, An Annotated Bibliography of California Fiction, 1664-1970 (Georgetown, Calif.: Talisman Literary Research, 1971).

8. William Coyle, ed., Ohio Authors and Their Books (Cleveland, Ohio: World Publishing, 1962).

9. E. F. Bleiler, The Checklist of Science-Fiction and Supernatural Fiction (Glen Rock, N.J.: Firebell Books, 1978).

10. Philip E. Hager and Desmond Taylor, The Novels of World War I: An Annotated Bibliography (New York: Garland, 1981). 
11. H. H. Heins, A Golden Anniversary Bibliography of Edgar Rice Burroughs (West Kingston, R.I.: Donald M. Grant, 1964).

12. P. Alfred Lee, A Bibliography of Christopher Morley (New York: Doubleday, Doran, 1935).

13. Mary E. Bell, Mammy's Story and Verses (Baltimore, Md.: Stockton Press, n.d.).

14. R. Glenn Wright, V.1, p.iii.

15. Adam Abet, Social Conscience (Bridgeport, Conn.: Co-operative Publishing Co., 1920).

16. Samuel Hopkins Adams, The Beggar's Purse (Boston: Smith \& Porter, 1918).

17. Kate Anderson, A Fight against Odds (Chicago: Woman's Temperance Publishing Assn., 1903).

18. Isabella Andrews, The Failure of Cunningham (Richmond, Va.: Hampton Institute, 1908).

19. Julia Keim Baker, The Wandering Joy (New York: Broadway Publishing, 1910).

20. C. H. Beazley, Crackerlings and Caramels (New York: Broadway Publishing, 1910).

21. Edward David Baron, The Inscrutable Woman (New York: Broadway Publishing Company, 1910).

22. G. Thomas Tanselle, "The Historiography of American Literary Publishing," Studies in Bibliography 18:3-5 (1965).

23. The Archives of Harper and Brothers, 1817-1914 (Cambridge and Teaneck, N.J.: ChadwyckHealey Microfilm Edition, 1980). 


\section{ACQUISITION PERSPECTIVES}

1. ANY BOOK IN PRINT .... means delivery to your library of all available books from any publisher or distributor in the U.S. or Canada. There is no list of publishers you must check ... WE DELIVER THEM ALL .... including trade, scientific/technical, text, university presses, paperbacks, associations, small presses, Canadian, and software.

Send us your direct orders and experience the "added value" received when using Book House.

\section{COMPLAL DAHWRY}

\section{OPAN ORDAR RAPORTS}

4 ACCURFTI BOOK DHIVHEY

\section{CALL TOLL-FREE TODAY 1-800-248-1146}

In Canada \& Michigan CALL COLLECT (517) 849-2117

OCLC Vendor No. 17397

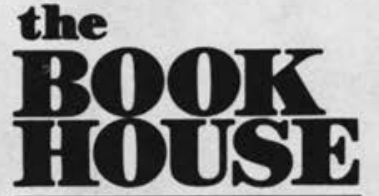

JOBBERS SERVING LIBRARIES WITH ANY BOOK IN PRINT SINCE 1962 208 WEST CHICAGO STREET JONESVILLE, MICHIGAN 49250 


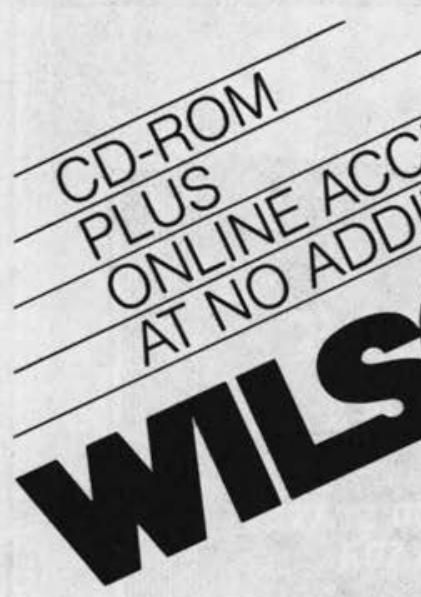

WILSONDISC OFFERS - CD-ROM Access

Search each database on a separate compact disc. And, with the touch of a button, you can update your search online-at no additional charge!

\section{- Online Access}

For access to the most current data, subscribers to each WILSONDISC database receive unlimited online search time in that database. You pay only the nominal hourly telecommunications rate-no additional charge!

\section{Four Search Modes for Users at All Levels 1 BROWSE Mode}

The same access points as the familiar Wilson printed indexes.

\section{WILSEARCH \\ Mode}

Easy-to-follow menu options simplify search formulation.

\section{WILSONLINE ${ }^{\otimes}$ Mode}

The same commands available with the WILSONLINE online retrieval system.

\section{EXPERT Mode}

Expanded screen handling, windowing functions, and more.

\section{WILSONDISC Databases}

Each database is available as a separate compact disc updated and cumulated quarterly.

- Applied Science \& Technology Index

\section{- Art Index}

- Biography Index

- Business Periodicals Index

- Cumulative Book Index

- Education Index

- General Science Index

- Humanities Index

- Index to Legal Periodicals

- Library Literature

- Readers' Guide to

Periodical Literature

- Social Sciences Index
Unlimited Online

Searching with Your WILSONDISC Subscription

Subscribers to a WILSONDISC database can also take advantage of unlimited online searching in that database for the entire term of their subscription. The only additional fee is the nominal WILSONDISC telecommunications charge.

\section{SPECIAL OFFER! \\ Demonstration Disc \\ Available}

The specially-priced WILSONDISC Demonstration Disc contains six months of data from 16 Wilson databases, and allows all of the CD-ROM search capabilities available with WILSONDISC. The Demonstration Disc is available at $\$ 99$, deductible from your first invoice for a regular WILSONDISC database subscription.

\section{To Order Call Toll-Free:} 1-800-367.6770
f In New York State call
1-800-462-6060; in Canada, cal collect 212-588-8400.

\section{THE H.W. WILSON COMPANY}

950 University Ave.

Bronx, NY 10452

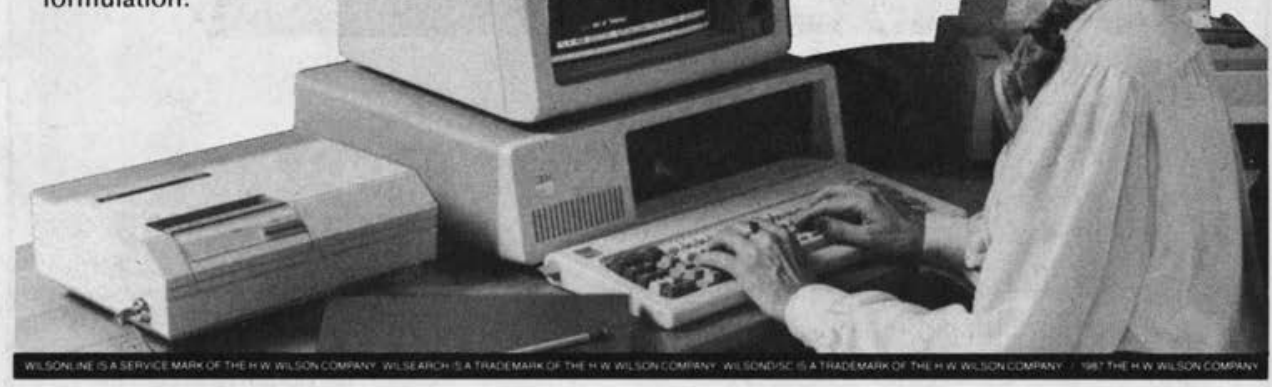

